\title{
DEVELOPING INFORMATION SEARCH AUTONOMY BASED ON DIFFERENTIATED TEACHING OF READING IN UNDERGRADUATES OF PHILOLOGY MAJORS IN GERMAN LANGUAGE
}

$$
\begin{aligned}
& \text { DESENVOLVENDO AUTONOMIA DE BUSCA DE INFORMAÇÃO BASEADA NO ENSINO } \\
& \text { DIFERENCIADO DE LEITURA EM GRADUANDOS DE FILOLOGIA EM LÍNGUA ALEMÃ }
\end{aligned}
$$

\section{DESARROLLO DE LA AUTONOMÍA EN LA BÚSQUEDA DE INFORMACIÓN A PARTIR DE LA ENSEÑANZA DIFERENCIADA DE LA LECTURA EN ESTUDIANTES DE LICENCIATURA EN FILOLOGÍA DE LA CARRERA DE LENGUA ALEMANA}

\author{
Vyacheslav M. Shovkovyi ${ }^{1}$ \\ Tetiana A. Shovkova ${ }^{2}$ \\ Tetiana P. Druzhchenko ${ }^{3}$ \\ Olena H. Tkachenko ${ }^{4}$ \\ Nataliia V. Semian ${ }^{5}$
}

\begin{abstract}
The purpose of the study is to identify how the differentiated teaching of reading used in teaching the German Language influences the development of information search autonomy in the tertiary students majoring in Philology. The study employed quasi-experimental research that used mixed-methods to collect qualitative and quantitative data. The study was of a one-group only type. German Language proficiency, reading skills, students' self-efficacy were the variables for the study. The study found that The differentiated teaching of reading used in teaching the German Language had positively influenced the development of information search autonomy in the tertiary students majoring in Philology which was measured at the pre-treatment and post-treatment stages through the variables such as German Language proficiency, reading skills, and students' self-efficacy. Due to the approach used in the study, the sampled students experienced a statistically significant change in all the variables. The German Language proficiency level increased by 18,1 grades, test grades in reading skills improved by 21.00 grades, and students' self-efficacy increased by 1.53 points. The values obtained through the calculation of correlations between the variables showed a statistically significant correlation between them. There was a positive relationship between GLPT and GLRST $(r=.51, p>.05)$; between GLP and SSE $(r=71, p<.01)$; and between GLRS and SSE $(r=.53, p>.05)$.
\end{abstract}

\footnotetext{
${ }^{1}$ Taras Shevchenko National University of Kyiv, Kyiv, Ukraine.

${ }^{2}$ Taras Shevchenko National University of Kyiv, Kyiv, Ukraine.

${ }^{3}$ Taras Shevchenko National University of Kyiv, Kyiv, Ukraine.

${ }^{4}$ Taras Shevchenko National University of Kyiv, Kyiv, Ukraine.

${ }^{5}$ Taras Shevchenko National University of Kyiv, Kyiv, Ukraine.
} 
Keywords: Undergraduates, information search autonomy, differentiated teaching of reading, German Philology majors, technology.

Resumo: $O$ objetivo do estudo é identificar como o ensino diferenciado da leitura utilizado no ensino da Língua Alemã influencia o desenvolvimento da autonomia na busca de informação em alunos do ensino superior de Filologia. O estudo empregou uma pesquisa quase experimental que utilizou métodos mistos para coletar dados qualitativos e quantitativos. $O$ estudo era do tipo apenas um grupo. Proficiência na língua alemã, habilidades de leitura, autoeficácia dos alunos foram as variáveis para o estudo. $O$ estudo constatou que o ensino diferenciado da leitura utilizado no ensino da Língua Alemã influenciou positivamente o desenvolvimento da autonomia na busca de informação nos alunos do ensino superior com especialização em Filologia, medida nas fases de pré e pós-tratamento por meio de variáveis como Língua Alemã proficiência, habilidades de leitura e autoeficácia dos alunos. Devido à abordagem utilizada no estudo, os alunos da amostra experimentaram uma mudança estatisticamente significativa em todas as variáveis. O nível de proficiência na língua alemã aumentou em 18,1 notas, as notas de teste em habilidades de leitura melhoraram em 21,00 notas e a autoeficácia dos alunos aumentou em 1,53 pontos. Os valores obtidos por meio do cálculo das correlações entre as variáveis mostraram correlação estatisticamente significativa entre elas. Houve uma relação positiva entre GLPT e GLRST ( $r=0,51, p>0,05)$; entre GLP e SSE $(r=71, p<0,01)$; e entre GLRS e SSE $(r$ $=0,53, p>0,05)$.

Palavras-chave: Graduandos, autonomia na busca de informação, ensino diferenciado da leitura, cursos de Filologia alemã, tecnologia.

Resumen: El objetivo del estudio es identificar cómo la enseñanza diferenciada de la lectura utilizada en la enseñanza de la lengua alemana influye en el desarrollo de la autonomía de búsqueda de información en los estudiantes de educación superior de la carrera de Filología. El estudio empleó investigación cuasi-experimental que utilizó métodos mixtos para recopilar datos cualitativos y cuantitativos. El estudio fue de un solo grupo. El dominio del idioma alemán, las habilidades lectoras, la autoeficacia de los estudiantes fueron las variables del estudio. El estudio encontró que la enseñanza diferenciada de lectura utilizada en la enseñanza de la lengua alemana había influido positivamente en el desarrollo de la autonomía de búsqueda de información en los estudiantes de educación terciaria de la carrera de Filología, la cual se midió en las etapas de pretratamiento y postratamiento a través de variables como el idioma alemán. competencia, habilidades de lectura y autoeficacia de los estudiantes. Debido al enfoque utilizado en el estudio, los estudiantes de la muestra experimentaron un cambio estadísticamente significativo en todas las variables. El nivel de dominio del idioma alemán aumentó en 18,1 grados, las calificaciones de las pruebas en habilidades de lectura mejoraron en 21,00 grados y la autoeficacia de los estudiantes aumentó en 1,53 puntos. Los valores obtenidos mediante el cálculo de correlaciones entre las variables mostraron una correlación estadísticamente significativa entre ellas. Hubo una relación positiva entre GLPT y GLRST ( $r=.51$, $p>.05)$; entre GLP y SSE ( $r=71$, $p$ $<.01)$; $y$ entre GLRS y SSE ( $r=.53, p>.05)$.

Palabras clave: Estudiantes universitarios, autonomía en la búsqueda de información, enseñanza diferenciada de la lectura, carreras de Filología Alemana, tecnología.

\section{INTRODUCTION}

Reading is a key students' skill helping them perceive a large amount of information, enrich their experience, gainthe education, and communicate. This skill is particularly important in teaching foreign languages because, in addition to the informative function (collecting, accumulating, 
processing, and sharing information), it also performs educational (reading texts illustrate speech patterns that students imitate in their productive speech) and integrative ones (it integrates language skills, as well as teaching a language with teaching culture and professional skills development) (Kung, 2019; Shovkovyy \& Shovkova, 2019).The authors' teaching experience reveals that students (in particular 1st-year students) have different levels of foreign language proficiency (including that in reading): from $A 2$ to $B 1+$ (though there are some students with the B2 level of proficiency). Such diversity of students requires differentiation in teaching, aimed to create individual trajectories of learning and development for each individual that provides for the creation of optimal conditions for each student, taking into account their abilities, possibilities, proficiency level, etc. We define the obtaining by students their personal optimal and maximum results in foreign language reading at the end of the first year as a priority, rather than obtaining the same level of reading proficiency (which in general is impossible). At the same time, we claim that the achievement of these results is impossible unless student work is integrated with their individual work, which requires a certain level of education and information search autonomy (ISA) (which is currently possible in teaching foreign languages only with the use of information and communication technologies). Thus, a student is able to determine their level of proficiency (including reading competence), make use of educational and information resources when choosing a variety of reading texts according to their own proficiency level, the content of which fully covers educational functions, to collect, processing and distribute information; to overcome difficulties in understanding the content and semantics of a foreign language text. The ISA can provide a trajectory of individual competence development in foreign language reading for each student. Therefore, the problem of the development of the autonomy mentioned in the conditions of differentiated teaching (DT) of foreign language reading is relevant and pertinent.

\section{THEORETICAL FRAMEWORK}

\section{Differentiated teaching of reading}

The differentiated instruction in foreign languages, and reading particularly, is recommended by the teachers and scientists to be based on individual psychophysiological characteristics, proficiency level, communicative needs of learners (Chamot, 2012; Naka, 2018). Moreover, the differentiated teaching is implemented in all components of the methodological system - in purposes, content, methods, methodological techniques, complexes of exercises, forms of teaching, methods, and forms of control. The DTR methodology is based on taking into account students' proficiency level (level of foreign language skills), level of presupposition knowledge, level of academic autonomy, students' personal learning styles. However, despite some achievements in the field of DTR, the issue of developing information search autonomy in Philology majors using the differentiated teaching reading in German has been underrepresented in the research (Csillag, 2016).

\section{Learner autonomy\& student's information search autonomy}

Especially in higher education institutions (HEI's) efforts have been made to integrate the competence concept in curricula although critics argue that integrating 'measurable' items such as competences has negatively affected the -hard to measure- values inherent to education and sustainability (Lambrechts \& Van Petegem, 2016). 
Due to the above, educational autonomy (the ability to take responsibility for one's educational activity in all its aspects: setting goals, defining content and consistency, choosing methods and techniques, managing the process of mastering, evaluating the result (Whyte, 2014) is defined as one of the key concepts of the competence. It is our deep conviction, that a person who possesses not only relevant knowledge, skills, and abilities, but also is ready to face new societal and work challenges, is capable of "rebooting": to upgrade and deepen knowledge, to acquire new skills, and abilities (which sometimes contradict those acquired a few years ago), to reflect (objective self-assessment and introspection), to autonomously perform the professional activity as well as to learn and self-educate, to practically use the strategies of educational and professional activity (Müller-Frommeyer et al, 2016).

Autonomy is defined as self-initiative and self-regulation, which correlate with the motivational and action (procedural) spheres of a person. Autonomy is a component of a variety of activities - domestic, professional, educational. It is learner autonomy that falls within the scope of our research. Learner autonomy is understood as the ability to reflect (awareness of knowledge they lack, self-examination of knowledge gaps, gaps in skills and abilities, assessment of proficiency level, skills and abilities), ability to seek information, self-planning of the self-study process) (Shvareva, 2011). Learner autonomy, as a characteristic of the competence that can be formed, determines the student's ability to define their proficiency level, as well as independently manage their self-study process, work with information sources, find, evaluate and process information.

For Meirieu (2019), autonomy consists in learning how to conduct ourselves. According to Linard (2003) autonomy is a higher-level capacity, cognitive but also psychological and social, which involves the qualities of attention, self-control, intelligence, self-confidence and relational confidence, which few people initially posses.Also recently, investigations into the possibility of classroom autonomy in EFL countries have highlighted uncertainties or various degrees of achievement due to factors related to teachers and learners, as well as specific cultural and socio-political characteristics (Bajrami L., 2015). Given the complex conceptualisation of teacher autonomy and intricate contextual influences, teachers must have a chance to reflect upon or evaluate their practice to maintain or increase their level of autonomy.

Learner autonomy is defined as one of the key characteristics of reading competence: the latter is understood as a system of extra-lingual knowledge, lexical, grammatical, phonetic skills, paralinguistic knowledge, a range of reading skills and strategies that determine the ability and willingness to interpret and comprehend (depending on the purpose of reading) written texts of different styles, genres and pragmatics at the semantic, metasemiotic and metametasemiotic levels (Shovkovyy \& Shovkova, 2019). Based on the definition of an autonomous student who can reflect on their studies through knowledge about learning, this concept can be defined as the process of teaching foreign language reading that includesfostering students' reflection related to the assessment of reading skills and the dynamics of their development; autonomy in the search for information resources and literature (what exactly and what it will be read for), in the collection, processing, preservation (recording), use of information of lingual and extra-lingual character; autonomy in the choice of reading strategies according to the communicative goals; autonomy in the choice of means of access to literature; autonomy in determining the means and forms of control to maximize objectivity in evaluation.

Given the above thestudent's information search autonomy (ISA) in this study is interpreted as the ability to find information resources and to collect, process, store, distribute, display information obtained (within competences being formed). The level of ISA is determined by the factors that follow: motives and needs for information search; the level of awareness in the subject area, which dictates 
the nature of the content, scope, ways of presenting information (the lower the level of awareness in a particular subject area is, the simpler the way of presenting information should be); awareness of information resources (which are relevant and integrate certain groups of people), command of information search software; the level of command of the language as a whole and the sublanguage of a certain field of knowledge the information belongs to; the ability to objectively evaluate the quality and nature of information in accordance with its potential to be perceived; a factor of progress and informational novelty: from each text read, the student shall obtain new information (in the conditions of foreign language teaching, this information can be both lingual and extralingual); formation of metacognitive strategies - search, analysis, systematisation, storage, dissemination of necessary information; the ability to solve problems related to information search and processing.

The ISA depends mainly on the individual characteristics of a student - their motives and needs, individual knowledge, awareness in the subject area and information resources, level of command of the language, and the subject sublanguage, metacognitive strategies - perception, processing, gathering, storage and use of information. Therefore, the formation of the ISA should be differentiated and based on the individual characteristics of each student.

We define the student's ISA in the conditions of the DTR in German as the ability to autonomously find and process information resources (which contain educational and authentic German-language materials), as well as authentic and educational texts that to the fullest extent possible fulfil educational functions and correspond to the student's proficiency level.

The ISA in reading foreign language texts in the conditions of DT covers the following:

- awareness of diagnostic resources through which a student can check and evaluate their reading competence, as well as their ability to use them effectively;

- the ability to autonomously and adequately assess the level of their language proficiency as well as reading competence;

- awareness of resources that contain information that characterizes the levels of foreign language proficiency in general and reading in particular;

- awareness of basic information and educational resources that correspond to the level of students' reading competence;

- the ability to use electronic search systems for reading texts, to apply strategies of skimming, scanning, and in-depth reading depending on communicative purposes;

- the ability to evaluate information resources as for compliance with their goals and the content of teaching reading;

- the ability to select texts, the content of which fully performs educational functions (corresponds to the relevant subject matter, has a novelty factor: contains important and cognitive information, new vocabulary, new cultural concepts, and realities);

- the ability to autonomously use information resources to overcome the problems of content and semantic understanding of a foreign language text;

- the ability to collect, accumulate, process information from authentic texts, and disseminate information to one's classmates by preparing multimedia presentations.

Based on the conclusions by Druzhchenko (2018), who argued that the level of learner autonomy coincides with the proficiency level, we distinguished three differentiated subgroups (DSG) 
of students such as a)with high proficiency level $(B 1+, B 2)$ and with the high level of learner autonomy; b)with intermediate proficiency level (B1) and with an intermediate level of learner autonomy;C)low proficiency level (A2) and low level of learner autonomy.

Therefore, the purpose of the study is to identify how the differentiated teaching of reading used in teachingthe German Language influences the development of information search autonomy in the tertiary students majoring in Philology.

The hypotheses were formulated to address the above research purpose.

H_0-the differentiated teaching of reading used in teaching the German Language will not influence the development of information search autonomy in the tertiary students majoring in Philology.

H_1 - the differentiated teaching of reading used in teaching the German Language will influence the development of information search autonomy in the tertiary students majoring in Philology.

\section{METHODS AND MATERIALS}

\section{Proceedings}

This was quasi-experimental research that used mixed-methods to collect qualitative and quantitative data.The study was of a one-group only type. German Language proficiency, reading skills, students' self-efficacy were the variables for the study. The research design was a three-stage one comprising the empirical study aimed at examination of best international and local language teaching practices to identify the gap for the study, the experimental study consisting of the pre-test and post phaseswhose purpose was to identify how the differentiated teaching of reading used in teaching the German Language influences the development of information search autonomy in the tertiary students majoring in Philology. It was usedto test the hypotheses. This was accompanied by measurements and statistical data collection, and the analytic stage that was dedicated to the consolidation and processing of the yielded data. The study started in September 2019 and was completed in March 2020.

\section{Description of the differentiated teaching of reading approach}

The development of information search autonomy in Philology majors using differentiated teaching reading in German is carried out consistently (see Figure 1). 


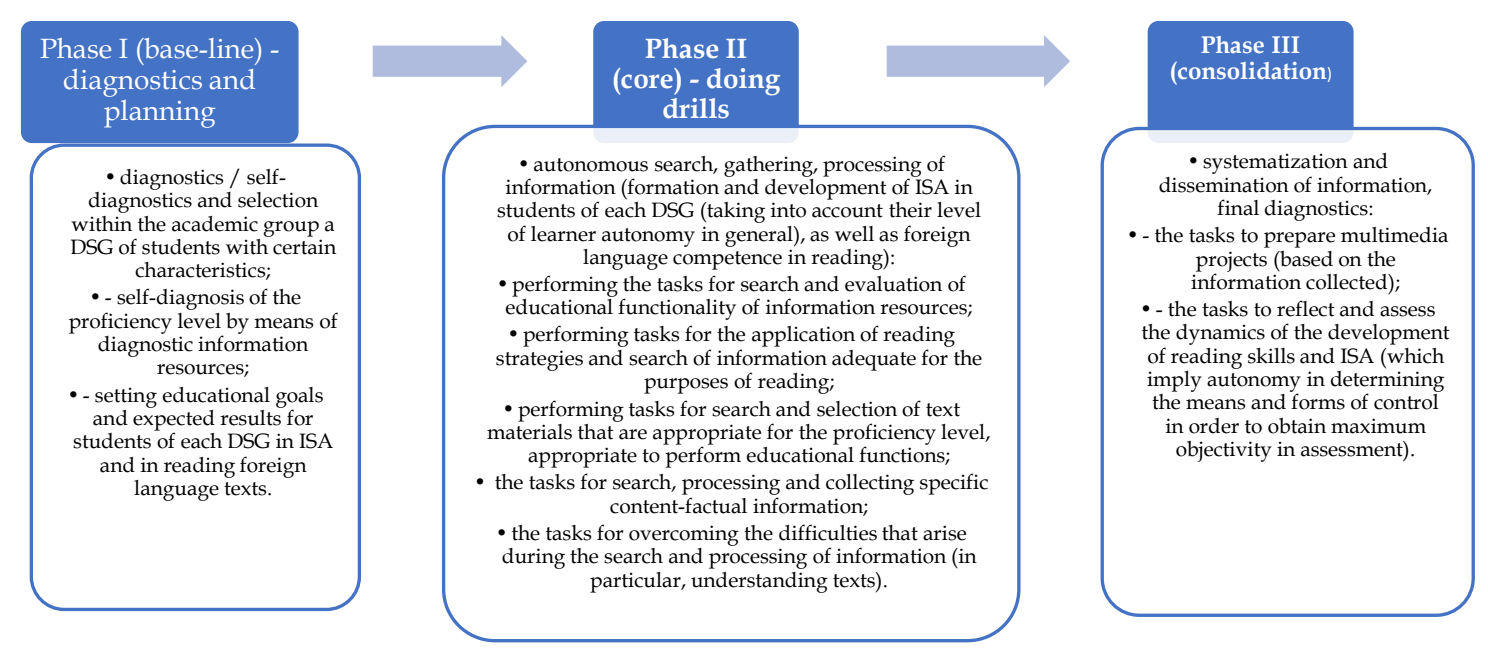

Figure 1. Development of information search autonomy in Philology majors using differentiated teaching reading in German.

Additionally, Phase II is focused on creating individual learning trajectories for students of different DSGs: each student should be able to autonomously find the necessary resources to determine their reading competence, to select texts for reading (which are the most effective for each student and the DSG as a whole), as well as resources that accompany this process (online electronic dictionaries, manuals, additional articles, etc.). Phase III ends with the teacher's assessment of the level of foreign language reading skills and ISA (see Figure 2). 


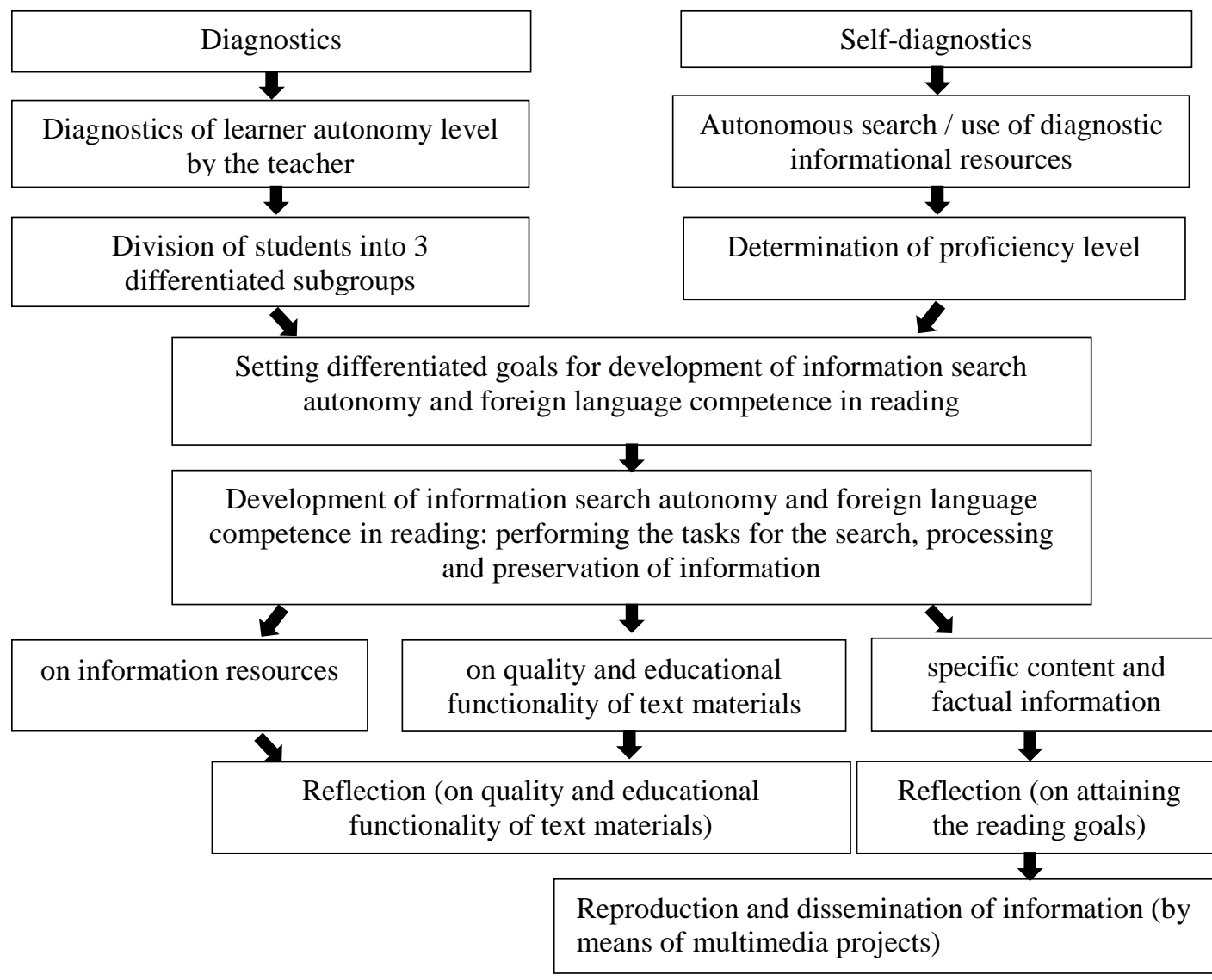

Expected results: the students have developed ISA and foreign language competence in reading at the level optimal for the student's abilities

Figure 2. The model of development of information search autonomy in Philology majors in the conditions of differentiated teaching of reading in German

Information resources are defined to be the main means for developing the ISA in reading foreign language texts in the conditions of differentiated teaching. We treat information resources as a special kind of resource, based on the ideas and knowledge accumulated as a result of scientific and technological activities of people in a certain subject area, and submitted in the form suitable for accumulation, implementation, and reproduction (Shvachych et al., 2017). Considering the content of the ISA in reading foreign language texts in the conditions of differentiated teaching, as well as taking into account the phasing in teaching reading (before-text (removal of lingual and extra-lingual reading difficulties), pre-text (formulation of tasks that determine the goals of reading), after-text (reproduction, discussion, the extension of the information received), we consider it appropriate to classify information resources focused on the development of the specified autonomy into three groups.

\section{Group 1}

Diagnostic information resources:

- resources that contain information on the qualitative characteristics of the language proficiency levels:

for example, https://www.goethe.de/ins/de/de/kuv/stu.html; kievskiyruo.edu.kh.ua/Files/downloads/zagalnoyevrop_rekom.doc;https://www.goethe.de/Z/50/commeuro /303.htm (Gemeinsamer europäischer Referenzrahmen für Sprachen: Lernen, lehren, beurteilen); 
http://alpha-intensiv.com.ua/urovni.html (German Levels); https://www.sprachenatelierberlin.de/de/topic/3729.deutsch-als-fremdsprache-niveaustufen.html (Niveaustufen - Deutsch als Fremdsprache); https://www.dw.com/de/der-gemeinsame-europ\%C3\%A4ische-referenzrahmenf\%C3\%BCr-sprachen/a-1633204 (Der Gemeinsame Europäische Referenzrahmen für Sprachen); http://www.europaeischer-referenzrahmen.de/ (Aufgaben des Gemeinsamen Europäischen Referenzrahmen für Sprachen (GER)); https://www.uni-hamburg.de/allgemeinsprachen/ueberuns/up-ger-u-kurzinfo.pdf (Gemeinsamer europäischer Referenzrahmen für Sprachen, 2004);

- resources that contain materials for defining a foreign language proficiency level (in particular, reading):https://www.goethe.de/ru/spr/kup/tsd.html (testen sie ihr deutsch goethe); https://www.sprachtest.de/einstufungstest-deutsch (Deutsch Einstufungstest); https://www.actilingua.com/en/learn-german-online-test/(ActiLingua German Online Test, 2019); https://sprachportal.integrationsfonds.at/deutschpruefungen/online-uebungstest (Die Online

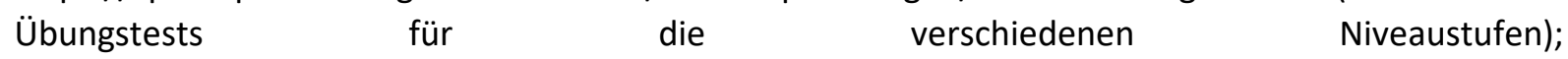
https://www.telc.net/fileadmin/user_upload/deutsch-test-fuer-zuwanderer_uebungstest_1_1_.pdf $\begin{array}{llllll}\text { (ÜBUNGSTEST } & 1 & \text { DEUTSCH-TEST } & \text { FÜR } & \text { ZUWANDERER, }\end{array}$ https://learngerman.dw.com/en/placementDashboard (Placement Test, 2020); https://www.deutsch-perfekt.com/deutsch-ueben/einstufungstest-niveau (Deutsch-Einstufungstest).

Group 2

Relevant information resources:

- online educational and information resources (containing foreign language texts for teaching reading) for example, https://www.deutsch-lernen.com/learn-germanonline/beginners/summary.php; https://lifeistgut.com; https://www.deutsch-perfekt.com/deutschlesen; https://www.deutsch-lernen-online.net/lesen; https://lingua.com/de/deutsch/lesen/; https://www.alumniportal-deutschland.org/deutsche-sprache/deutsch-auf-die-schnelle/;

https://www.goethe.de/de/spr/kup/prf/bar.html; $\quad$ https://www.deutschalsfremdsprache.ch/; https://www.dw.com/de/deutsch-lernen/sprachbar/s-9011; online authentic information resources (which contain authentic non-educational text materials), for example, https://www.dw.comhttps://www.dw.com; https://www.leselupe.de/buecher-onlinelesen.php;https://www.deutschland.de/de; https://newsburger.de/; https://www.spiegel.de/; https://www.tagesschau.de/; $\quad$ https://www.t-online.de/; $\quad$ https://www.stern.de/; https://web.de/magazine; https://www.nachrichtenleicht.de/; https://www.tatsachen-ueberdeutschland.de/de/jugend; https://www.deutschlands-natur.de/; https://de.wikipedia.org/wiki/Wikipedia:Hauptseite.

\section{Group 3}

Information resources of dissemination information:

- resources that serve to create and publish presentation materials (Powerpoint software; and also Prezi; Haiku Deck; Apple Keynote; SlideRocket; SlideDog; Slides), including multimedia presentations that contain text, photos, videos, slide- shows, sound design, animation, 3D graphics, etc.

The development of ISA in reading foreign language texts in the conditions of differentiated teaching with the use of information resources is carried out by means of appropriate tasks. Here are some examples.

Tasks of Phase I (base-line) 
Task 1. Learning objectives: To form the awareness of information resources that are used to diagnose the proficiency level in German (including reading proficiency), to form the skills necessary to self-diagnose the proficiency level by means of information resources.

Activity outline:

For students with a high level of autonomy and proficiency in German within B1 + and B2: find 2-3 articles in the German language about the levels of foreign language proficiency (including reading proficiency) on the Internet. Read them, learn about these levels.

For students with an intermediate level of autonomy and proficiency in German within B1: find 2-3 articles in the German language about the level of foreign language proficiency (including reading proficiency) on the Internet. Read them, learn about these levels (if you have trouble finding information, use the resource https://www.goethe.de/Z/50/commeuro/303.htm). Relate your proficiency level in German to the levels described. Find online tests on German authentic websites (if you have problems finding information, use the resource https://learngerman.dw.com/en/placementDashboard or https://www.actilingua.com/en/learngerman-online-test/), do them, and define your proficiency level in German (including reading proficiency).

For students with low autonomy and proficiency in German within A2: read materials that characterize foreign language proficiency levels using the resources (if you experience significant difficulties when reading in German, refer to Ukrainian translations); find 1-2 resources that describe the level of foreign language proficiency.

Relate your proficiency level in German to the levels described. Using the information resource https://learngerman.dw.com/en/placement-test-a2/l-36697405, define your proficiency level in German (including reading proficiency). Without assistance find another information resource that contains online tests in the German language and does these tests. Compare the results of the two tests.

Expected result: Students learn about diagnostic resources, learn to work with them, determine the proficiency level in German (including reading proficiency).

Tasks of Phase II (core)

Task 2.1. Learning objectives: formation of information resources search skills and assessment of their educational functionality.

Activity outline:

For students with a high level of autonomy and proficiency within B1 + and B2: Using the Internet search systems, find 3-4 information resources containing authentic German-language texts that you can use during your 1st year. To evaluate the educational functionality of the site, pay attention to its design and content: the design of the site, the rubrics it contains: make a general overview of these sections, the nature of the site (educational and informational or purely informational), targeting (what its target audience is), subject matter, content and the volume of materials, interactive engagement, the availability of online interaction.

For students with a low level of autonomy and proficiency in German within A2: Among the following information resources (https://www.deutsch-perfekt.com/, https://www.deutsch-lernenonline.net/, https://lingua.com/de/deutsch/lesen/) Choose one that contains text materials that you can use during your 1 st year of learning a foreign language. To evaluate the educational functionality 
of the site, pay attention to its design and content (the same as for students with a high level of autonomy). Using the Internet search engine and the algorithm for information resource analysis, find 1-2 information resources containing German-language texts that you can use during your first year.

Expected result: students acquire skills necessary for the information resources search as well as for the assessment of their educational functionality according to their personal learning opportunities.

Task 2.2. Learning objectives: to develop skills in applying reading strategies and searching information relevant to the goals of reading; as well as the ability to find and select textual materials that are relevant to the proficiency level and suitable for educational purposes.

The task was developedbased on the theme "Landschaften in Deutschland (Natural Landscapes of Germany)".

Activity outline:

For students with a high level of autonomy and proficiency in German within B1 + and B2: using the Internet search systems, find 2-3 information resources that contain authentic German-language texts about the natural landscapes of Germany. Find and record (for further presentation and discussion) information on the natural landscapes of Germany.

Follow the algorithm of proceeding:

- determine the suitability of the site to your reading needs;

- if the site is appropriate, find the texts on the relevant topic and content (focusing on headlines, keywords, non-verbal indications, etc.);

- if the text corresponds to the theme and content, find information about the natural landscapes of Germany;

- read the snippets (with the full understanding of all the details) about the particular natural landscapes of Germany, determine to what extent linguistic and non-linguistic information is valuable to you;

- if the information lacks novelty, start searching for another information resource.

For students with an intermediate level of autonomy and proficiency in German within B1: Analyse information resources https://www.voucherwonderland.com/reisemagazin/naturwunder-indeutschland/ https://diercke.westermann.de/content/deutschland-landschaften-978-3-14-100800-552-1-1. Find and record (for further presentation and discussion) information on the natural landscapes of Germany.

Follow the algorithm of proceeding:

- analyse the site interface (verbal and non-verbal characteristics), establish the correspondence to your reading needs;

- if the site is appropriate, find the texts of relevant topic and content (focusing on headings, keywords, text highlights, annotations, non-verbal cues);

- if the text meets all the parameters mentioned above, find information on German natural landscapes (focus on the subheadings, availability of the keywords in the text you entered into the search box earlier, the first and the last sentence of the paragraph); 
- pay attention to the length of text (or snippet) you need to read with the full understanding of all the details, read the first few sentences, and define the approximate percentage of understanding;

- evaluate the length, the complexity of the text and the time required to process it (and, on the other hand, the availability of new verbal and factual information), determine the feasibility of further work with this text (fragment);

- read snippets (with the full understanding of all the details) about the landscape of the Alps; determine to what extent linguistic and non-linguistic information is valuable to you;

- if the text is not too difficult and possesses informative value, read it, work with new vocabulary, record the information needed for further discussion and presentation;

- if the text does not meet the parameters mentioned above, search for another text.

Using the Internet search systems and the algorithm for information resource analysis, find 23 information resources that contain German-language texts about the natural landscapes of Germany, read these texts, and record the necessary information.

For students with a low level of autonomy and proficiency in German within A2: Analyse information resources https://www.medienwerkstattonline.de/lws_wissen/vorlagen/showcard.php?id=6177\&edit=0, https: // www. study-ingermany.de/de/deutschland-entdecken/deutsche-landschaft/. Find and record (for further presentation and discussion) information on the natural landscapes of Germany.

Follow the algorithm of proceeding - the same algorithm is applied as for the students of a differentiated subgroup with an intermediate level of autonomy.

Using the Internet search systems and the algorithm for information resource analysis, find 12 information resources that contain German-language texts about the natural landscapes of Germany, read these texts, and record the necessary information.

Expected result: students acquire the skills to apply reading strategies and those for information search, relevant to their reading goals.

Tasks of Phase III (consolidation)

Learning objectives: to develop the skills to select, organize, process, and represent information using a multimedia presentation.

Within the topic "Natural Landscapes of Germany".

Activity outline:

For students with a high level of autonomy and proficiency within B1 + and B2: use online information resources and prepare a multimedia presentation on the natural landscapes of Europe: the presentation should include text, video/audio, photo materials, etc.

For students with an intermediate level of autonomy and proficiency in German within B1: use the online resource (https://www.voucherwonderland.com/reisemagazin/naturwunder-indeutschland/ https://diercke.westermann.de/content/deutschland-landschaften-978-3-14-100800-552-1-1), find 3-4 additional resources (which are not too difficult for you and contain relevant information) and prepare a multimedia presentation on the natural landscapes of Germany: the presentation should have text, video/audio, photo materials, etc. 
For students with a low level of autonomy and proficiency in German within A2: use online resources

(https://www.medienwerkstattonline.de/lws_wissen/vorlagen/showcard.php?id=6177\&edit=0, https: // www .study-in-Germany.de / de / deutschland-entdecken / deutsche-landschaft /), find 1-2 additional resources (which are not too difficult for you and contain relevant information) and prepare a multimedia presentation on the natural landscapes of Germany: the presentation should have text, video/audio, photo materials, etc.

Expected result: students acquire the skills to select, organize, process, and represent information using a multimedia presentation.

The logic of differentiated instructions is based on the following principles:

- students with a high level of autonomy and proficiency in German within B1 + and B2 work according to the algorithms of proceeding that they use when searching for information resources and texts (while the teacher control is minimal at the stage of discussion of what the students have read), students should be creative in the selection of information resources, extend beyond the resources used by the teacher and other students, to disseminate new information resources among classmates; at the same time, students should be able to orient themselves in the information space and, based on complex algorithms, select exactly those resources that have high educational functionality;

- students with an intermediate level of autonomy and proficiency in German within B1 also work with search algorithms (but teacher control is more sufficient), which are more detailed, serve as a tool for rational selection of information resources and texts; unlike the DSG with a high level of autonomy, the students in this subgroup receive 1-2 resources selected by the teacher, analyse them according to the established algorithm, acquire the skills of effective search, then proceed to autonomous search;

- students with a low level of autonomy and proficiency in German within A2 also work with search algorithms (teacher control in these DSGs is much more sufficient than in the previous ones): students analyse 2-3 information resources/texts under teacher control, acquiring appropriate algorithms of proceeding, then proceed to the autonomous search of 1-2 resources/texts;

- students of each DSG carry out an autonomous search for information resources and texts for reading (although the level of autonomy is inversely proportional to the level of teacher control);

- students should develop ISA, teacher control should be gradually reduced, there should be a transition from semi-autonomy (teacher-led) to full autonomy (when students can autonomously set and solve search tasks);

-students' DSGs are dynamic, i.e. their composition should change in the course of acquiring autonomous actions when searching for information resources and texts for reading.

\section{Sampling}

The study relied on the convenience sample who were 62 Bachelor's students ( 24 males aged 19-22 and 38 female students aged 19-22) majoring in Philology (German Language) for National University of Life and Environmental Sciences of Ukraine, Kyiv, Ukraine. The participants were considered mutually homogeneous as they were seeking a degree in the same major. 


\section{Instruments}

German Language Proficiency Test (GLPT), German Language Reading Skills Test (GLRST), and Students' Self-Efficacy Test (SSET) were used as instruments to measure the changes in the variables. The validity and reliability of the GLPT and GLRST were established by three experts, who assessed every task for clearness, relevance, and concreteness using the 4-point scale ( $1=$ 'absolutely unclear' and 'absolutely irrelevant' up to $4=$ 'absolutely clear' and 'absolutely irrelevant'). The experts' values were used the assess the content validity of the tests (the Content Validity Index) (CVI)) as recommended byRodrigues et al. (2017). The below formula was used for calculations.

$$
\mathrm{CVI}=\frac{n=\text { raters who assessed every test item using the values from } 1 \text { to } 4}{n=\text { total number of raters }}
$$

The test item was considered valid and relevant if the Mean value was greater than 3.00 (75\%).

Additionally, DIF and DTFmethods were used to analyse tests' validity and reliability. The significance level was 0.01 . The values yielded from the DTF analyses that were higher than 0.14 were used as an indicator of a substantial DTF for those tests.

The SSET was borrowed for Sachitra and Bandara (2017). It consists of 20 items and was validated for content and construct by the researchers.

\section{RESULTS}

The study results showed that the differentiated teaching of reading used in teaching the German Language had positively influenced the development of information search autonomy in the tertiary students majoring in Philology which was measured at the pre-treatment and post-treatment stages through the variables such as German Language proficiency, reading skills, and students' selfefficacy. As can be seen in Table 1, due to the approach used in the study, the sampled students experienced a statistically significant change in all the variables.

Table 1. Results of the pre-treatment and post-treatment measurements of the variables such as German Language proficiency, reading skills, and students' self-efficacy.

\begin{tabular}{|l|l|l|l|l|l|l|l|l|}
\hline \multirow{2}{*}{} & \multicolumn{2}{|c|}{ M } & \multicolumn{2}{c|}{ SD } & \multicolumn{2}{c|}{ SS } & t & \multirow{2}{*}{ p - value } \\
\cline { 2 - 8 } & B & A & B & A & B & A & & \\
\hline GLP & 63.11 & 81.21 & 2.47 & 2.13 & 1233.33 & 1143.11 & -2.4867 & .0031 \\
\hline GLRS & 65.29 & 86.29 & 2.15 & 2.11 & 1214.12 & 1151.05 & -1.5667 & .0033 \\
\hline SSE & 3.12 & 4.65 & 2.54 & 2.43 & 1217.21 & 1131.04 & -1.7239 & .0028 \\
\hline
\end{tabular}

Note: $\mathrm{B}-$ before treatment; $\mathrm{A}-$ after treatment; $p<.05$ 
The German Language proficiency level increased by 18,1 grades, test grades in reading skills improved by 21.00 grades, and students' self-

efficacy increased by 1.53 points. The study found a good correlation between the variables (see Table 2).

Table 2. Correlations Between Variables.

\begin{tabular}{|l|l|l|l|}
\hline Variables & $\mathbf{1}$ & $\mathbf{2}$ & $\mathbf{3}$ \\
\hline 1. GLP & 1.00 & & \\
\hline 2. GLRS & $.51^{*}$ & 1.00 & \\
\hline 3. SSE & $.71^{* *}$ & $.53^{*}$ & 1.00 \\
\hline Mean (Likert type mean score) & $80.13(4.65)$ & $93.01(4.94)$ & $67.54(4.37)$ \\
\hline Standard Dev. & 12.11 & 15.77 & 4.64 \\
\hline
\end{tabular}

${ }^{*} p>.05 .{ }^{* *} p<.01$

Values in Table 2 show a statistically significant correlation between the variables. There is a positive relationship between GLPT and GLRST $(r=.51, p>.05)$; between GLP and SSE $(r=71, p<.01)$; and between GLRS and SSE $(r=.53, p>.05)$.

\section{DISCUSSION}

The study sought to identify how the differentiated teaching of reading used in teaching the German Language influenced the development of information search autonomy in the tertiary students majoring in Philology. It found that the differentiated teaching of reading used in teaching the German Language had positively influenced the development of information search autonomy in the tertiary students majoring in Philology which was measured at the pre-treatment and post-treatment stages through the variables such as German Language proficiency, reading skills, and students' self-efficacy. Due to the approach used in the study, the sampled students experienced a statistically significant change in all the variables. The German Language proficiency level increased by 18,1 grades, test grades in reading skills improved by 21.00 grades, and students' self-efficacy increased by 1.53 points. The values obtained through the calculation of correlations between the variables showed a statistically significant correlation between them. There was a positive relationship between GLPT and GLRST ( $r=.51, p>.05)$; between GLP and SSE $(r=71, p<.01)$; and between GLRS and SSE ( $r=.53, p>.05)$.

The results go in line with Bajrami (2015) stating that differentiated reading strategies used in foreign language classes help the students better succeed in their academic performance. It is consistent with West (2018) and Erturk (2016) who proved that reading helped the learners develop their autonomy in both readings and searching for information to share their experiences within the established reading communities. It agrees with Nation and Waring (2019) who claim that reading fluency improves language fluency in general.

The study boosted the theory and methods of Foreign Language teaching (Hall, 2017; Stapleton \& Shao, 2018), skill-based foreign language teaching/training (Arifani, 2016; Rajeswaran, 2018; Son, 2018) training the students' reading skills using differentiated teaching (King et al., 2009; Simmons, 2015). 


\section{CONCLUSION AND RECOMMENDATIONS}

The study found that the student's ISA is an important component of foreign language reading competence, and its formation should be based on a differentiated approach - taking into account both the level of student autonomy and proficiency level. The ISA in reading provides for the awareness of diagnostic, educational, and information resources, as well as the skills to search for new ones, relevant to the level of foreign language competence in reading and goals of foreign language teaching, skills to collect, accumulate, process information from authentic texts, and disseminate it employing multimedia presentations, the ability to use information resources autonomously to overcome the problems of understanding the content and semantics of a foreign language text. The key means for developing this autonomy are the German-language information resources, which are classified into three groups: diagnostic, relevant information resources, information resources of information dissemination. The realization of the author's methodology is implemented in complexes of educational tasks, which are differentiated by the level of the ISA and the level of students' proficiency. The complex of tasks is focused on the gradual transition of students from semiautonomy to full autonomy in searching for information resources and reading texts. The differentiated teaching of reading used in teaching the German Language had positively influenced the development of information search autonomy in the tertiary students majoring in Philology which was measured at the pretreatment and post-treatment stages through the variables such as German Language proficiency, reading skills, and students' self-efficacy. Due to the approach used in the study, the sampled students experienced a statistically significant change in all the variables. The German Language proficiency level increased by 18,1 grades, test grades in reading skills improved by 21.00 grades, and students' self-efficacy increased by 1.53 points. The values obtained through the calculation of correlations between the variables showed a statistically significant correlation between them. There was a positive relationship between GLPT and GLRST $(r=.51, p>.05)$; between GLP and SSE ( $r=71, p<.01)$; and between GLRS and SSE $(r=.53, p>.05)$.

The recommendations for the teachers include such steps as the preliminary measurement/identification of the level of ISA in reading for each DSG. Students of DSG with high levels of ISA in foreign language reading can diagnose their proficiency level without the teacher supervision, set information search goals, use information resources they are aware of autonomously, find new effective information resources that can maximally ensure the achievement of educational goals. Moreover, they are able, without teacher's assistance, to organize, search for, process and gather necessary information; find necessary texts, make use of reading strategies and those for information search, solve problems connected with the understanding of the content of texts, demonstrate a high level of reflection. The students of the DSG with the intermediate level of the ISA in foreign language reading partly require teacher's assistance in the diagnosis of their proficiency level, defining the goals for information search. These students are assisted by the teacher in the search for information resources, but at the same time, the students can autonomously find new ones that contain materials that do not always meet the educational goals (for example, there is no novelty in the texts, the texts are inappropriate thematically, etc.), do not correspond to the student's proficiency level (they contain too complicated or too simple texts).The students need their teacher's assistance at the stage of planning (they should receive the tasks developed), organisation, the realisation of work on search, processing, and gathering of necessary information (the teacher from time to time controls and adjusts the students' search work); the students do not always use reading and information search strategies adequately; they need help in understanding the content of the texts and at large can evaluate their skills objectively. The students of the DSG with the low level of ISA in foreign language reading require constant teacher guidance in providing diagnostic and relevant information resources, in instructing on work with information resources; the teacher constantly sets educational tasks for individual work related to search, processing, gathering the necessary information, performs control and quality assessment functions at the various stages of work; the students are not able to effectively apply reading and information search strategies, they need constant monitoring to solve problems related to understanding the content of texts. 
Further research is needed in the dissemination of best practices and designsof the efficient training model for the teachers who are involved in teaching the undergraduates majoring in the German language.

\section{ACKNOWLEDGEMENT}

We express our thankfulness to everyone who contributed to this study to ensure that it could be completed smoothly.

\section{REFERENCES}

Arifani, Y. (2016). Optimizing EFL learners' sensitizing reading skills: development of local content-based textbook. English Language Teaching, 9(5), 1-7. https://doi.org/10.5539/elt.v9n5p1

Bajrami, I. (2015). Meeting students' diverse needs for reading through differentiated instruction strategies. Journal of Foreign Language Teaching and Applied Linguistics, 2. https://doi.org/10.14706/jfltal15235

Bajrami, L. (2015). Teacher's new role in language learning and in promoting learner autonomy. ProcediaSocial and Behavioral Sciences, 199, 423-427. https://doi.org/10.1016/i.sbspro.2015.07.528

Boa Sorte, P. (2020). Mark the correct answer? To whom? Deconstructing reading comprehension. Journal of Research and Knowledge Spreading, 1(1), 1-8.

Chamot, A. U. (2012). Chapter 6. Differentiated instruction for language and learning strategies: Classroom applications. In W. M. Chan, K. N. Chin, S. K. Bhatt \& I. Walker (Eds.), Perspectives on individual characteristics and foreign language education (pp. 115-130). Berlin, Germany, Boston, MA: De Gruyter Mouton.

Csillag, J. (2016). Differentiated reading instruction. New York, NY: Routledge.

Druzhchenko, T. P. (2018). Methods of differentiated training of future lawyers in English oral monologue of future lawyers (PhD thesis). Institute of Philology of Taras Kyiv National University, Kyiv, Ukraine.

Dias, A. F. (2020). Trans* escrevivências as a pedagogical power. Journal of Research and Knowledge Spreading, 1(1), 1-17.

Erturk, N. O. (2016). Language learner autonomy: Is it really possible? Procedia - Social and Behavioral Sciences, 232, 650-654. https://doi.org/10.1016/j.sbspro.2016.10.089

Ebrahimi, M. A. (2020). Cultural value of translation of proverbs and synopsis. Journal of Research and Knowledge Spreading, 1(1), 1-10.

Fullagar, S. (2019). A physical cultural studies perspective on physical (in)activity and health inequalities: the biopolitics of body practices and embodied movement. Revista Tempos e Espaços em Educação, 12(28), 63-76.

Hall, G. (2017). Language teaching methods. In G. Hall, G. Cook \& R. Carter, Exploring english language teaching (pp. 85-116). London, UK: Routledge.

King, R., Chapman, C., Weatherly, B., Kidd, C., \& Braxton, M. (2009). Differentiated instructional strategies for reading in the content areas [Video file]. Retrieved from 
http://sk.sagepub.com/video/differentiated-instructional-strategies-for-reading-in-thecontent-areas

Kung, F.-W. (2019). Teaching second language reading comprehension: the effects of classroom materials and reading strategy use. Innovation in Language Learning and Teaching, 13(1), 93-104. https://doi.org/10.1080/17501229.2017.1364252

Lambrechts, W., \& Van Petegem, P. (2016). The interrelations between competences for sustainable development and research competences. International Journal of Sustainability in Higher Education, 17(6), 776-795. https://doi.org/10.1108/ijshe-03-2015-0060

Linard, M. (2003). Self-study, ethics, and technologies: Challenges and paradoxes of autonomy. In B. Albero (Ed.), Humanities and social sciences/education (pp. 241-263). Paris, France: House of Human Sciences Foundation.

Meirieu, P. (2019). Autonomy. Philippe Meirieu's website: History and news of pedagogy. Retrieved from http://meirieu.com/DICTIONNAIRE/autonomie.htm

Müller-Frommeyer, L. C., Aymans, S. C., Bargmann, C., Kauffeld, S., \& Herrmann, C. (2016). Introducing competency models as a tool for holistic competency development in learning factories: Challenges, example, and future application. Procedia Manufacturing, 9, 307-314. https://doi.org/10.1016/j.promfg.2017.04.015

Naka, L. (2018). Differentiated instruction in English foreign language learning in undergraduate studies. Journal of Literature, Languages and Linguistics, 42, 102-112.

Nation, I. S. P., \& Waring, R. (2019). Developing reading fluency. In I. S. P. Nation \& R. Waring, Teaching extensive reading in another language (pp.123-135). New York, NY: Routlege.

Rajeswaran, M. C. (2018). Approaches to teaching english for specific purposes (ESP) in engineering programs. IUP Journal of English Studies, 13(3).

Rodrigues, I. B., Adachi, J. D., Beattie, K. A. et al. (2017). Development and validation of a new tool to measure the facilitators, barriers, and preferences to exercise in people with osteoporosis. $B M C$ Musculoskelet Disorders, 18, 540. https://doi.org/10.1186/s12891-017-1914-5

Shvachych, H. H., Tolstoy, V. V., Petrechuk, L. M., Ivashchenko, Y. S., Gulyaeva, O. A., \& Sobolenko, O. V. (2017). Modern information and communication technologies. Dnipro, Ukraine: National Metalurgic Academy of Ukraine.

Shovkovyy, V. M., \& Shovkova, T. A. (2019). Formation of reflection in future German philologists as a component of reading competence. Pedagogical Sciences: Theory, History, Innovative Technologies, 3(87), 117-132.

Simmons, R. M. (2015). The impact of differentiated instruction on student reading level throughout the response to intervention model (Masrter's thesis, St. John Fisher College, Rochester, NY). Retrieved from https://fisherpub.sjfc.edu/cgi/viewcontent.cgi?article=1311\&context=education_ETD_masters

Son, J. B. (2018). Language skill-based approach. In J. B. Son, Teacher development in technology-enhanced language teaching (pp. 89-107). Cham, Switzerland: Palgrave Macmillan.

Stapleton, P., \& Shao, Q. (2018). Research in language teaching over two decades: A retrospective of the first 20 volumes of Language Teaching Research. Language Teaching Research, 22(3), 350-369. https://doi.org/10.1177/1362168816688929 
West, G.B. (2018). Reading communities: developing autonomy in an ESL academic reading course. In A. Burns \& J. Siegel (Eds.), International perspectives on teaching the four skills in elt. international perspectives on english language teaching (pp. 167-178). Cham, Switzerland: Palgrave Macmillan.

Whyte, S. (2014). Introduction - theory, and practice in second language teaching with interactive technologies. In E.C. Schmid \& S. Whyte (Eds.), Teaching languages with technology: communicative approaches to interactive whiteboard use (pp. 1-22). London, UK: Bloomsbury Academic.

\section{$\underline{\text { ABOUT THE AUTHORS }}$}

\section{Vyacheslav M. Shovkovyi}

Department of Teaching Methodology of Ukrainian and Foreign Languages and Literatures, Institute of Philology, Taras Shevchenko National University of Kyiv, Kyiv, Ukraine.

E-mail: slav.shovk@gmail.com

ORCID: https://orcid.org/0000-0003-4876-2162

\section{Tetiana A. Shovkova}

Department of German Philology and Translation, Institute of Philology, Taras Shevchenko National University of Kyiv, Kyiv, Ukraine.

Email: tchovk@ukr.net

ORCID: https://orcid.org/0000-0002-2440-1293

\section{Tetiana P. Druzhchenko}

Department of Teaching Methodology of Ukrainian and Foreign Languages and Literatures, Institute of Philology, Taras Shevchenko National University of Kyiv, Kyiv, Ukraine.

E-mail: imagine tania@ukr.net

ORCID: https://orcid.org/0000-0002-8295-9674

\section{Olena H. Tkachenko}

Department of Teaching Methodology of Ukrainian and Foreign Languages and Literatures, Institute of Philology, Taras Shevchenko National University of Kyiv, Kyiv, Ukraine.

E-mail: alona.yarkova22@gmail.com

ORCID: https://orcid.org/0000-0002-6913-4627

\section{Nataliia V. Semian}

Department of Teaching Methodology of Ukrainian and Foreign Languages and Literatures, Institute of Philology, Taras Shevchenko National University of Kyiv, Kyiv, Ukraine.

E-mail: semian nv@gmail.com

ORCID: https://orcid.org/0000-0001-7148-4805 